\title{
New Insights Into Secondary Organic Aerosol Formation At The Air - Liquid Interface
}

\author{
Xiao Sui, ${ }^{\ddagger}, \dagger, *$ Bo Xu, ${ }^{\|}$Jenn Yao, ${ }^{\dagger}$ Oleg Kostko, ${ }^{\|}$Musahid Ahmed," and Xiao-Ying Yu ${ }^{\dagger, *}$ \\ ‡ College of Geography and Environment, Shandong Normal University, Jinan, 250358, China \\ ${ }^{\dagger}$ Energy and Environment Directorate, Pacific Northwest National Laboratory, Richland, WA, \\ 99354. \\ " Chemical Sciences Division, Lawrence Berkeley National Laboratory, Berkeley, CA. 94720, \\ USA
}

*Corresponding author e-mail: xiaoying.yu@pnnl.gov. Telephone: 1-509-372-4524 


\section{Table of Contents}

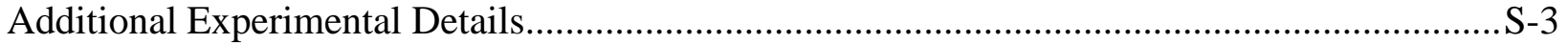

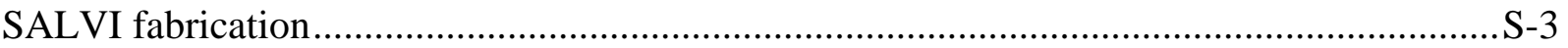

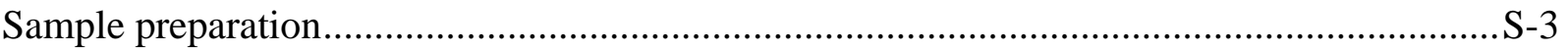

Vacuum ultraviolet single photon ionization mass spectrometry (VUV SPI-MS) setup.........S-3

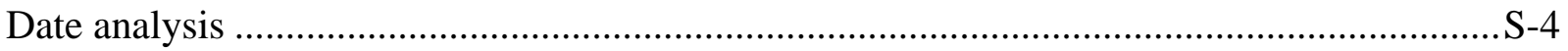

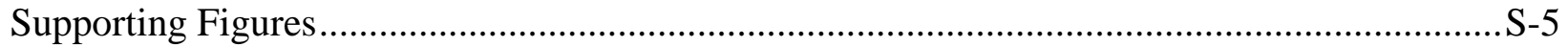

Fig. S1. VUV-SPIMS spectral comparison showing glyoxal control, 1 hr. 2 hr. and 4 hr. photochemical reaction products of glyoxal and hydrogen peroxide solutions at photon energy of $10.7 \mathrm{eV}$. Green drop lines stand for reactant, intermediates, and products; and red drop lines polymers/oligomers in UV samples.

Fig. S2. Typical VUV SPI-MS spectra acquired at PIE of $12.0 \mathrm{eV}$ from (a-b) the $2 \mathrm{hr}$. UV sample and (c- d) the $4 \mathrm{hr}$. UV sample.

Fig. S3. PIE curves and AEs of main fragments determined from the glyoxal control solution.

Fig. S4. Determination of AEs of key products from the $2 \mathrm{hr}$. UV aging data. Red arrows point to the onset of PIE curves.

Fig. S5. Determination of AEs of key products from the $4 \mathrm{hr}$. UV aging data. Red arrows point to the onset of PIE curves.

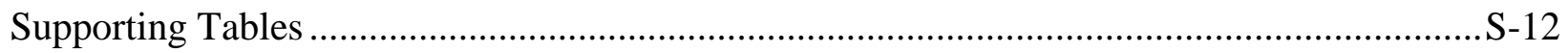

Table S1. Summary of experimental conditions. ....................................................... -12

Table S2. List of significant PDMS related peaks observed in the positive ion mode. ........S-13

Table S3. Proposed new pathways of glyoxal photochemical reactions at the a-l interface detected by in situ liquid VUV-SPIMS............................................................................

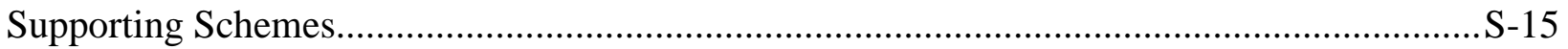

Scheme S1. Possible structures of representative new compounds identified by in situ liquid VUV-SPIMS 


\section{Additional Experimental Details}

SALVI fabrication

SALVI fabrication has been described in detail in our previous studies. ${ }^{1,2}$ Briefly, SALVI is a portable microfluidic reactor. It has a $200 \mu \mathrm{m}$ wide and $300 \mu \mathrm{m}$ deep microchannel and it is made of polydimethylsiloxane (PDMS) by soft lithography. The version used here has a microchannel underneath a silicon nitride (SiN) membrane that is $100 \mathrm{~nm}$ thick and the window area is $1.5 \times 1.5 \mathrm{~mm}^{2}$ (Norcada, Canada) on a silicon frame that is $200 \mu \mathrm{m}$ thick with an area of $7.5 \times 7.5 \mathrm{~mm}^{2}$. Two apertures of $2 \mu \mathrm{m}$ in diameter were milled using scanning electron microscopy with the focused ion beam (SEM-FIB). They are $100 \mu \mathrm{m}$ apart and located in the channel canter. ${ }^{3,4}$

Sample preparation

Glyoxal (40\% wt. in water, electrophoresis grade) and hydrogen peroxide $\left(\mathrm{H}_{2} \mathrm{O}_{2}, 30 \%\right.$ wt. in water, certified ACS grade) solutions were acquired from Sigma-Aldrich (St. Louis, MO, USA). They were used as received. The microchannel was cleaned using deionized water three times to minimize possible interference of PDMS. Solutions containing $5 \mathrm{mM}$ glyoxal, $20 \mathrm{mM} \mathrm{H}_{2} \mathrm{O}_{2}$ of approximate $100 \mu \mathrm{L}$ were mixed before getting injected to the microchannel by a syringe pump at a flow rate of $10 \mu \mathrm{L} / \mathrm{min}$. Excess $\mathrm{OH}$ was provided to meet the pseudo first-order of glyoxal reaction conditions. Oligomers and polymers could form due to the a-l surface oxidation of glyoxal according to previous studies. ${ }^{5,6}$ A Hg-Ar UV lamp (Oriel lamp model 6035, power supply model 6060, USA, wavelength $253.65 \mathrm{~nm}$ ) was used for UV illumination. The distance between the SiN membrane and the UV lamp was kept at $10 \mathrm{~cm}$ to simulate photochemical process of glyoxal and $\mathrm{H}_{2} \mathrm{O}_{2}$ in the atmosphere. A series samples with different UV aging times, including 1 hr., 2 hr. and 4 hr., were prepared. Detailed conditions were summarized in Table S1. Sample preparation was performed in the chemical analysis laboratory at the ALS.

Vacuum ultraviolet single photon ionization mass spectrometry (VUV SPI-MS) setup

After UV aging in the laboratory adjacent to the beamline, the SALVI device was brought to the beamline end station and fixed to the bottom electrode of the ion optics module of the VUV SPIMS immediately. ${ }^{4}$ The setup and pump down time was approximately $20 \mathrm{~min}$. for each sample, therefore about 20 min dark aging time was added for each sample due to sample installation. This SPI-MS was coupled with a three-meter VUV monochromator at the 9.0.2 Chemical Dynamics Beamline at the Advanced Light Source (ALS), Lawrence Berkeley National Laboratory. The SiN membrane was positioned $\sim 5 \mathrm{~mm}$ under the VUV photon flux by optimizing the height of the mass spectrometer. The molecules evaporated $\left(\sim 10^{8} /\left(\mathrm{cm}^{2} / \mathrm{s}\right)^{2}\right.$ from the two holes on the SiN membrane were ionized by the bright and tunable synchrotron VUV photon light. Meanwhile, the liquid in the microchannel membrane was withheld by its surface tension across the aperture, makes it possible to detect the evaporated molecules during experiments. ${ }^{1,2}$ To optimize signals, a microchannel plate (MCP) voltage was tuned to detect produced compounds. Eventually, the ions were collected and detected by the ToF mass spectrometer. ${ }^{3}$ SPI-MS measurements were acquired for photon energies ranging from 8.0 to $12.6 \mathrm{eV}$ for the $4 \mathrm{hr} ., 2 \mathrm{hr}$. UV aged and glyoxal control samples; and 8.0 to $11.0 \mathrm{eV}$ for the $1 \mathrm{hr}$. UV aged sample, respectively, with a $0.1 \mathrm{eV}$ step to obtain the photoionization efficiency (PIE) curve of each mass by integrating the peak intensities at each photon energy. These experiments were performed in two beam trips and the instrument setups were slightly different each time. Although the range of photon energies was different, same key products were observed among 
all UV aging samples (see in Table 1 and Fig. 2). These results indicated the chemical reactions were consistent despite the different scanned photon energies.

Date analysis

Mass calibration was performed by using known chemical species such as water, oxygen, or rare gases. ${ }^{3}$ Peaks were integrated and plotted in Origin ${ }^{\circledR}$. The mass to charge ratio at the peak center was used for peak identification. However, for different photon energies, the peak centers of compounds were slightly different. The first point on the PIE curve which deviated from background signal was taken as the appearance energy (AE) of the molecule. ${ }^{3}$ AEs were compared with literature reported ionization energy (IE) values to determine if they were in agreement or not. The AEs of key products were all less than $12.0 \mathrm{eV}$. However, many compounds would dissociate under high photon energies. Therefore, spectra at $12.0 \mathrm{eV}$ were chosen for peak identification, other mass spectra were also considered based on the photoionization efficiency curve. There was a difference in the total counts of the series samples, because each device containing samples treated differently had slightly different height between the UV photon beam due to their location, manual height adjustment, and instrument parameters between two different beamline visits. 


\section{Supporting Figures}
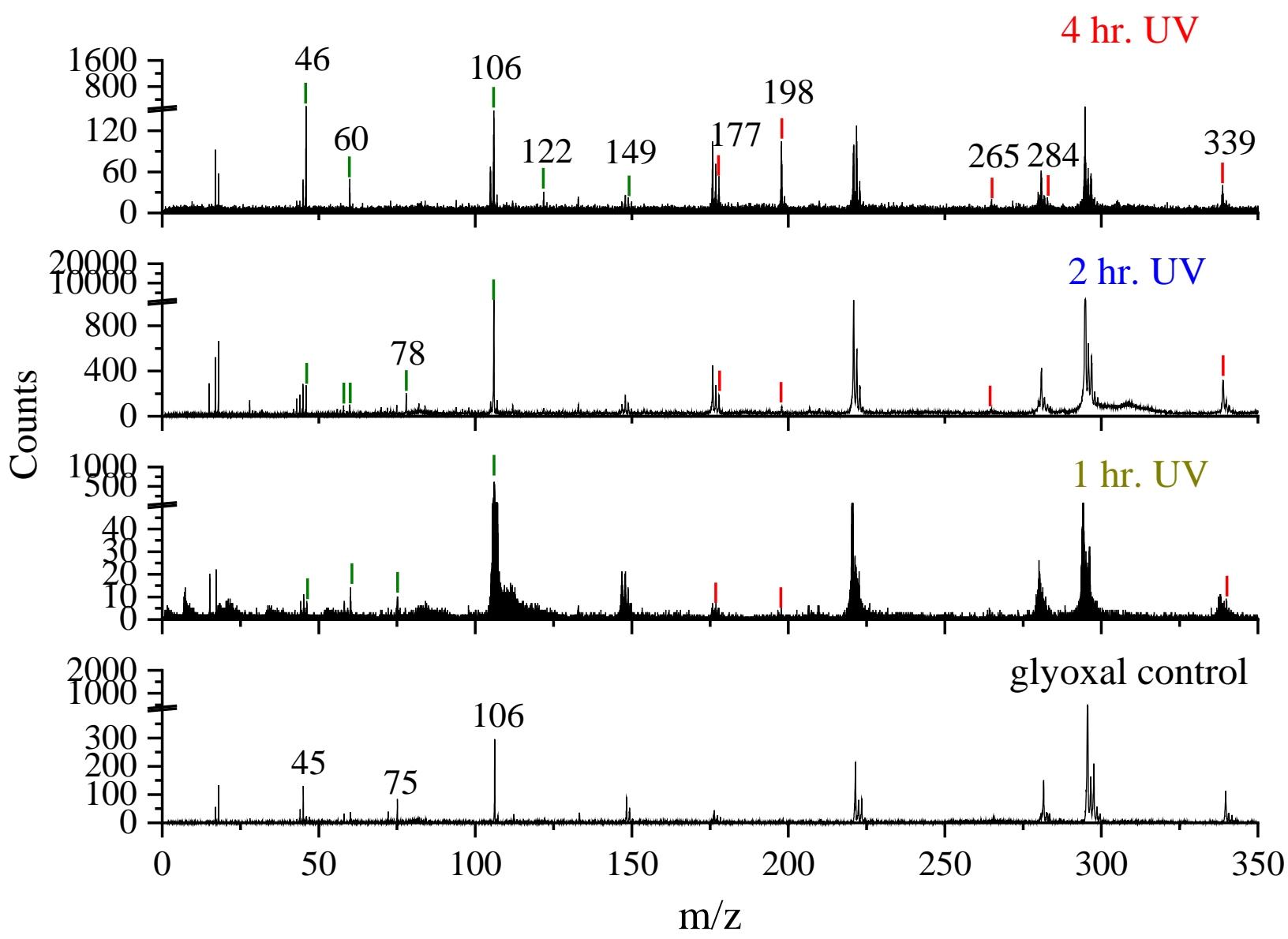

Fig. S1. VUV-SPIMS spectral comparison showing glyoxal control, $1 \mathrm{hr} .2 \mathrm{hr}$. and $4 \mathrm{hr}$. photochemical reaction products of glyoxal and hydrogen peroxide solutions at photon energy of $10.7 \mathrm{eV}$. Green drop lines stand for reactant, intermediates, and products; and red drop lines polymers/oligomers in UV samples.

The mass spectral comparison of glyoxal control, $1 \mathrm{hr} .2 \mathrm{hr}$. and $4 \mathrm{hr}$. UV aging samples at photon energy of $10.7 \mathrm{eV}$ in a mass range of m/z 1 - 350 was illustrated in Fig. S1. Each sample was injected into a pristine device and treated with or without light for a fixed amount of time right before being installed into the chamber. It is worth noting that each sample would have about 20 minutes of dark reactions added to the sample, which is equal to the duration of the main chamber pump down prior to VUV SPI-MS analysis. This additional short dark aging time is the same for every sample and therefore should not affect the overall results. The count difference observed in the spectral comparison arose mainly from the cell alignment in relation to the photon beam location. The distance between the top of the SiN membrane and the photon irradiation varied from run to run because the cell thickness varied slightly as well as of the height of the instrument chamber via manual adjustment to optimize photon irradiation. Better alignment would make the data more comparable in the future.

Peaks from glyoxal control and PDMS are marked without drop lines. Glyoxal photooxidation products, such as molecules and dissociative photoionization fragments of carboxylic acids, were 
observed in the positive ion mode and marked in green drop lines. Some examples include the following: formic acid (m/z 46), glycolaldehyde (m/z 60), and deprotonated tartaric acid (m/z 149). In addition, oligomer molecules and/or their fragments, such as $\mathrm{m} / \mathrm{z} 122\left(\mathrm{C}_{3} \mathrm{H}_{6} \mathrm{O}_{5}{ }^{+}\right), \mathrm{m} / \mathrm{z}^{+}$ $177\left(\mathrm{C}_{6} \mathrm{H}_{9} \mathrm{O}_{6}{ }^{+}\right), \mathrm{m} / \mathrm{z} 198\left(\mathrm{C}_{5} \mathrm{H}_{10} \mathrm{O}_{8}{ }^{+}\right), \mathrm{m} / \mathrm{z} 265\left(\mathrm{C}_{8} \mathrm{H}_{9} \mathrm{O}_{10}{ }^{+}\right), \mathrm{m} / \mathrm{z} 307\left(\mathrm{C}_{10} \mathrm{H}_{11} \mathrm{O}_{11}{ }^{+}\right)$and m/z 339 $\left(\mathrm{C}_{10} \mathrm{H}_{11} \mathrm{O}_{13}{ }^{+}\right)$were detected and marked in red drop lines. 

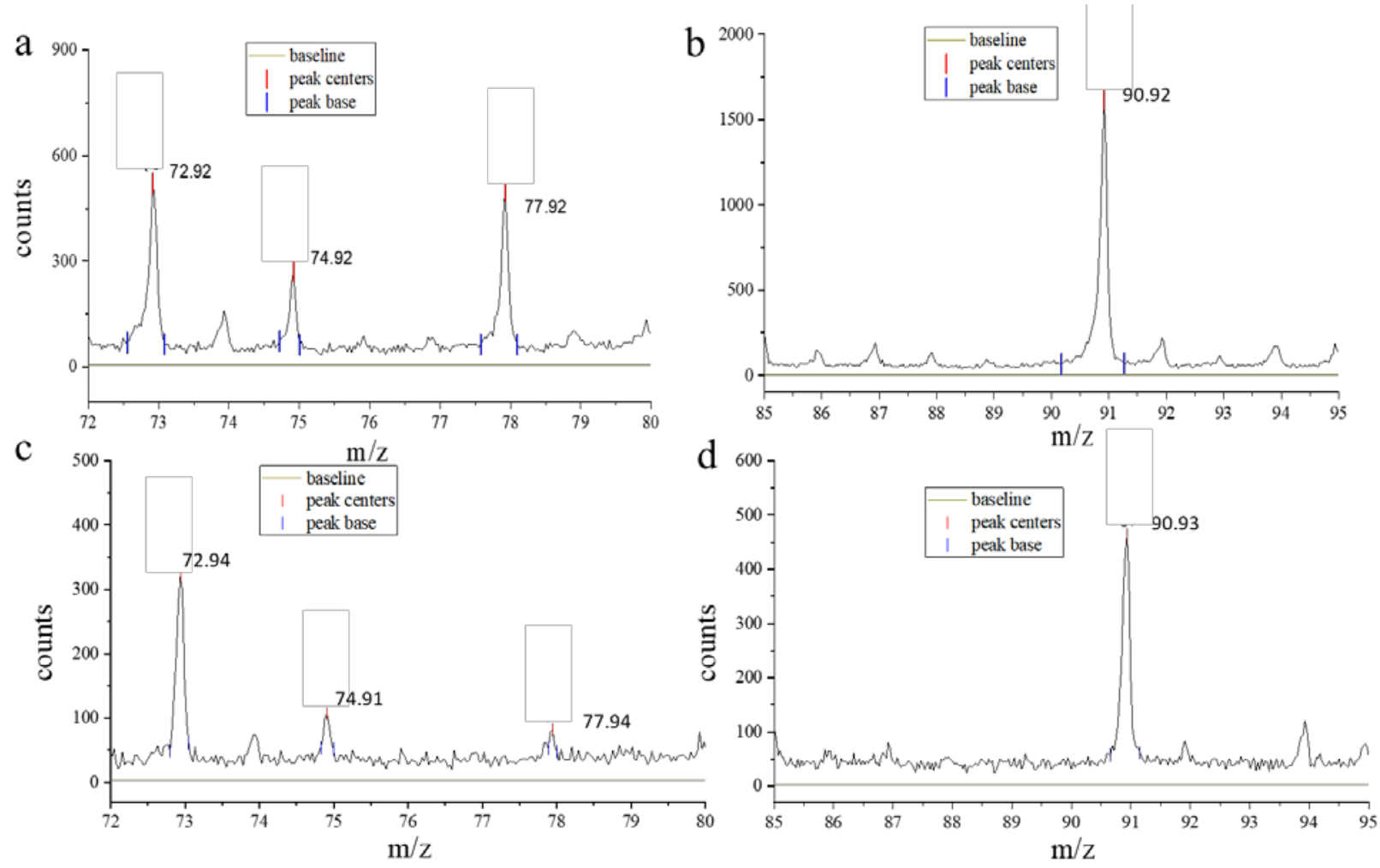

Fig. S2. Typical VUV SPI-MS spectra acquired at PIE of $12.0 \mathrm{eV}$ from (a-b) the $2 \mathrm{hr}$. UV sample and (c- d) the $4 \mathrm{hr}$. UV sample.

Figure S2 shows typical VUV SPI-MS spectra from the 2 hr. and 4 hr. UV treated-sample. In Fig. S2a, the parent signal $\left(\mathrm{m} / \mathrm{z}^{+} 74\right)$ of glyoxylic acid has a lower intensity compared to its deprotonated fragments (m/ $\left.\mathrm{z}^{+} 73\right)$. Similarly, the parent signal of glycolic acid $\left(\mathrm{m} / \mathrm{z}^{+} 76\right)$ has a low intensity compared to its deprotonated fragment $\left(\mathrm{m} / \mathrm{z}^{+} 75\right)$. This route was likely a result of the proton-transfer process. ${ }^{7}$ The monohydrated glycolaldehyde shows up at $\mathrm{m} / \mathrm{z}^{+} 78$.

In Fig. S2b, oxalic acid should appear at $\mathrm{m} / \mathrm{z}^{+} 90$ in the positive mode. However, we see only $\mathrm{m} / \mathrm{z}^{+} 91$, which probably arises as a result of proton transfer. ${ }^{6}$ 


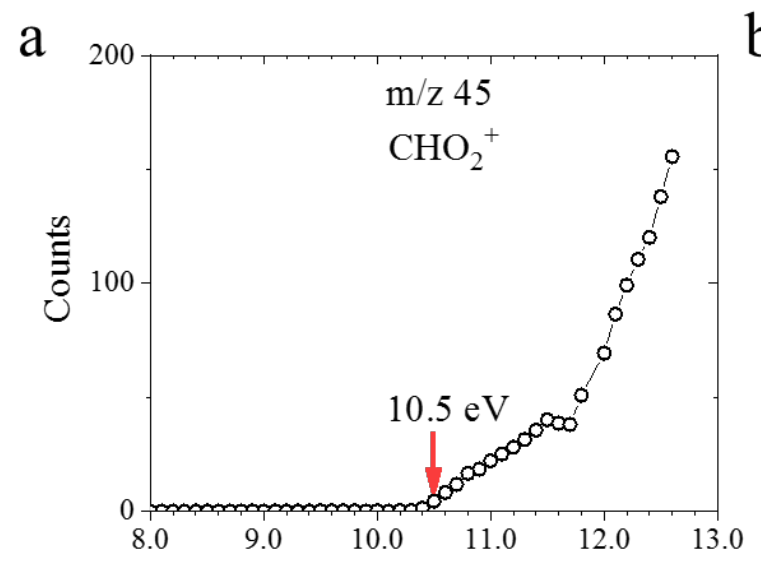

b
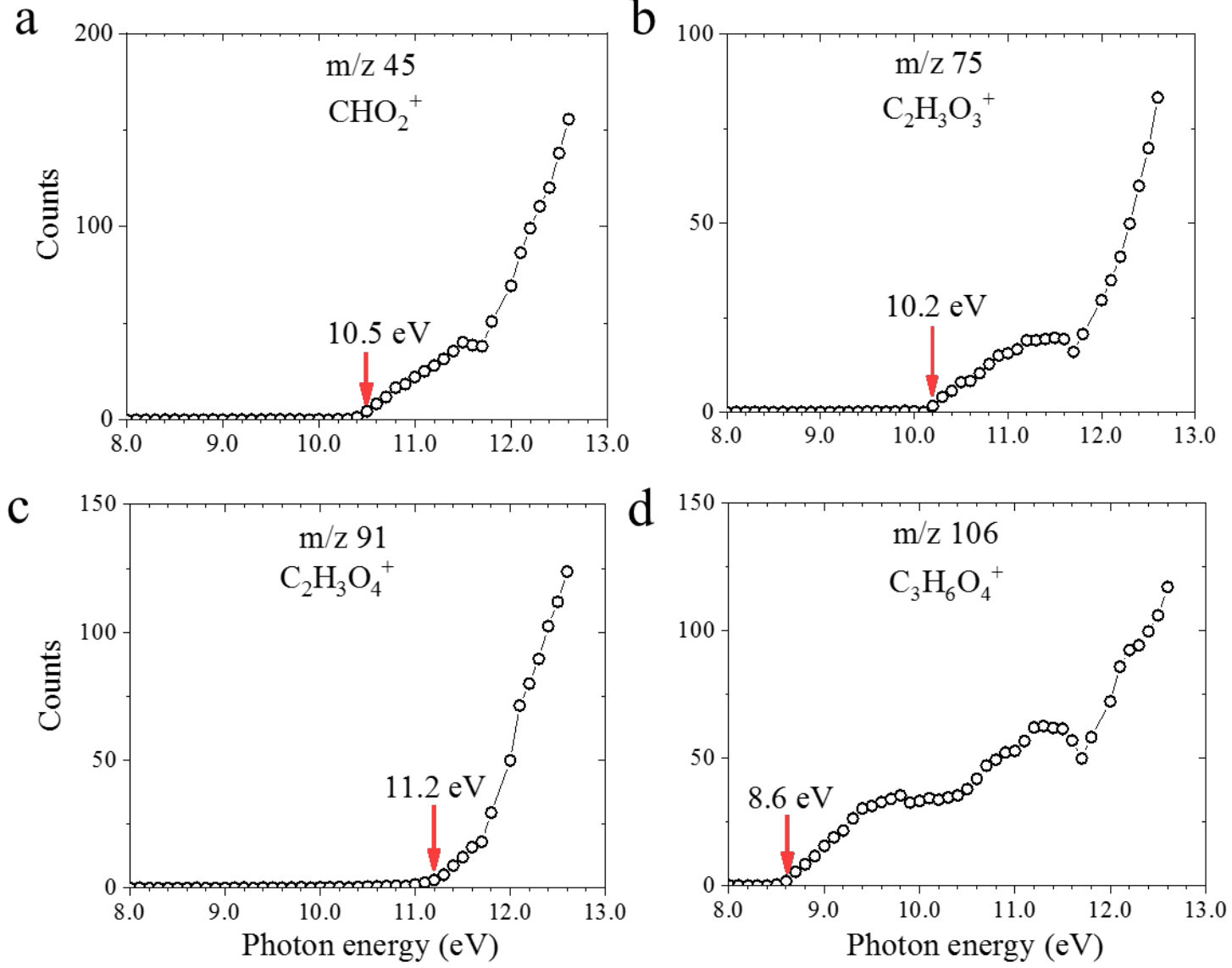

Fig. S3. PIE curves and AEs of main fragments determined from the glyoxal control solution.

AEs of main fragments determined from the glyoxal control observations were depicted in Fig. S3. Our results show some peaks are inherent of glyoxal itself not products of photochemical reactions. 


\section{Supporting Information}
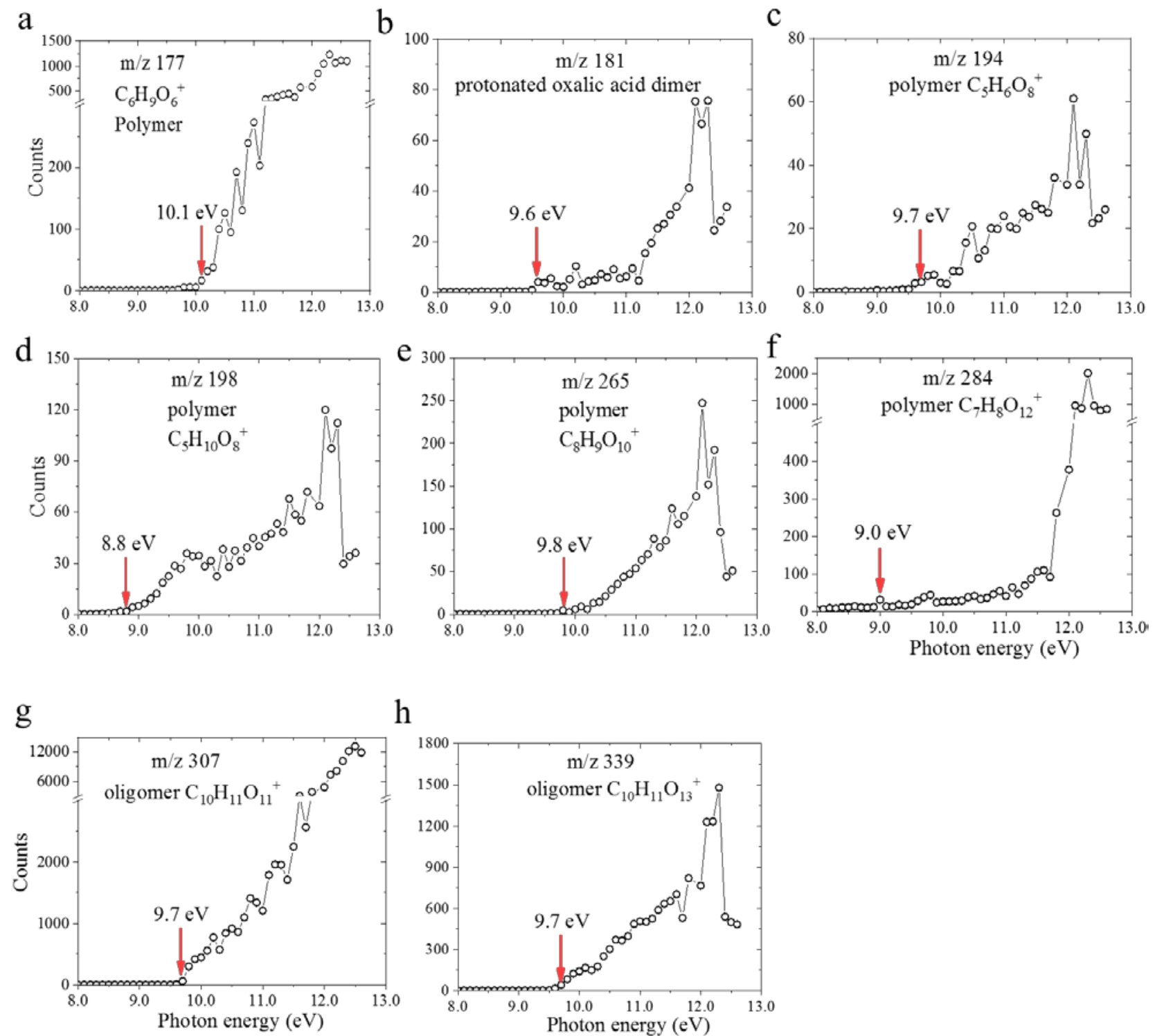

Fig. S4. Determination of AEs of key products from the $2 \mathrm{hr}$. UV aging data. Red arrows point to the onset of PIE curves.

In Fig. S4, the AEs of oligomers are shown as follows: $\mathrm{m} / \mathrm{z}^{+} 177 \mathrm{C}_{6} \mathrm{H}_{9} \mathrm{O}_{6}{ }^{+} 10.1 \mathrm{eV}$ (Fig. S4a), $\mathrm{m} / \mathrm{z}^{+} 181 \mathrm{C}_{4} \mathrm{H}_{5} \mathrm{O}_{8}{ }^{+} 9.6 \mathrm{eV}$ (Fig. S4b), m/z $\mathrm{z}^{+} 194 \mathrm{C}_{5} \mathrm{H}_{6} \mathrm{O}_{8}{ }^{+} 9.7 \mathrm{eV}$ (Fig. S4c), m/z $\mathrm{z}^{+} 198 \mathrm{C}_{5} \mathrm{H}_{10} \mathrm{O}_{8}{ }^{+}$ $8.8 \mathrm{eV}$ (Fig. S3d), m/z $\mathrm{z}^{+} 265 \mathrm{C}_{8} \mathrm{H}_{9} \mathrm{O}_{10}{ }^{+} 9.8 \mathrm{eV}$ (Fig. S4e), $\mathrm{m} / \mathrm{z}^{+} 284 \mathrm{C}_{7} \mathrm{H}_{8} \mathrm{O}_{12}{ }^{+} 9.0 \mathrm{eV}$ (Fig. S4f), $\mathrm{m} / \mathrm{z}^{+} 307 \mathrm{C}_{10} \mathrm{H}_{11} \mathrm{O}_{11}{ }^{+} 9.7 \mathrm{eV}$ (Fig. S4g), and $\mathrm{m} / \mathrm{z}^{+} 339 \mathrm{C}_{10} \mathrm{H}_{11} \mathrm{O}_{13}{ }^{+} 9.7 \mathrm{eV}$ (Fig. S4h). The AE results were summarized in Table 1 in the main text. 


\section{Supporting Information}

a

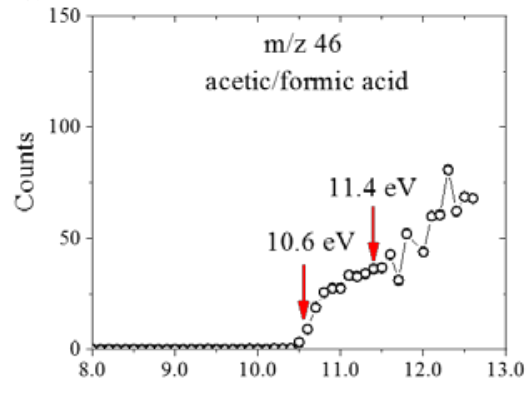

d

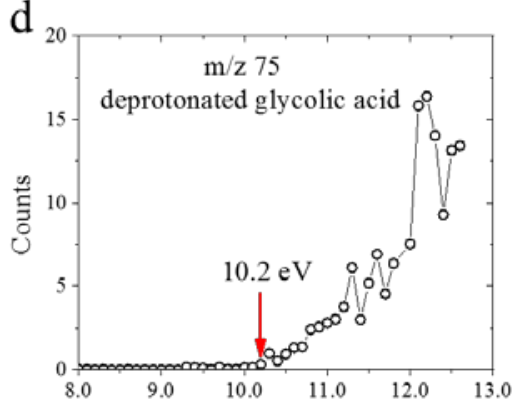

b

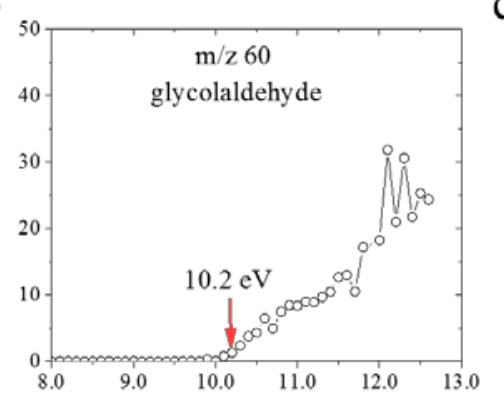

e

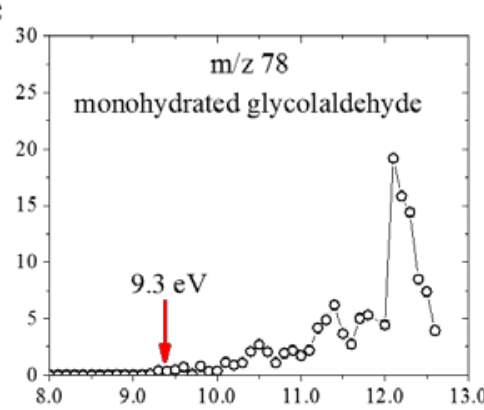

h
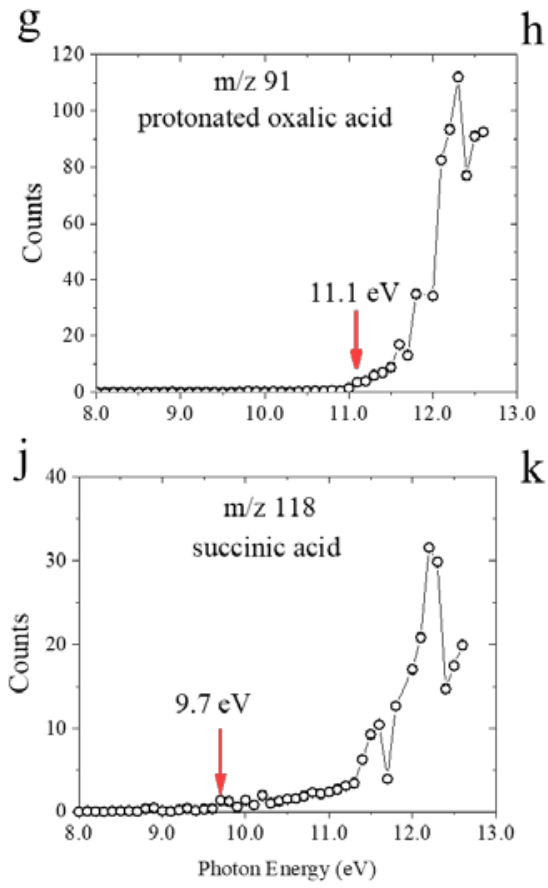
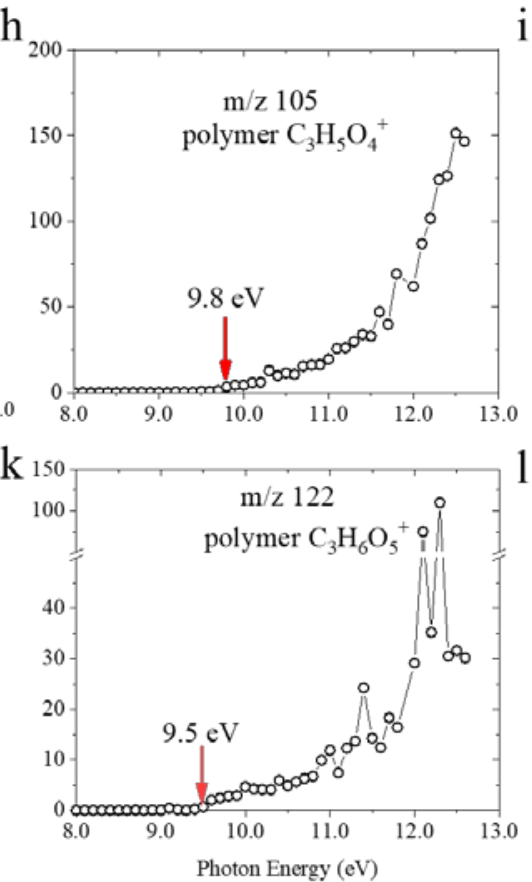
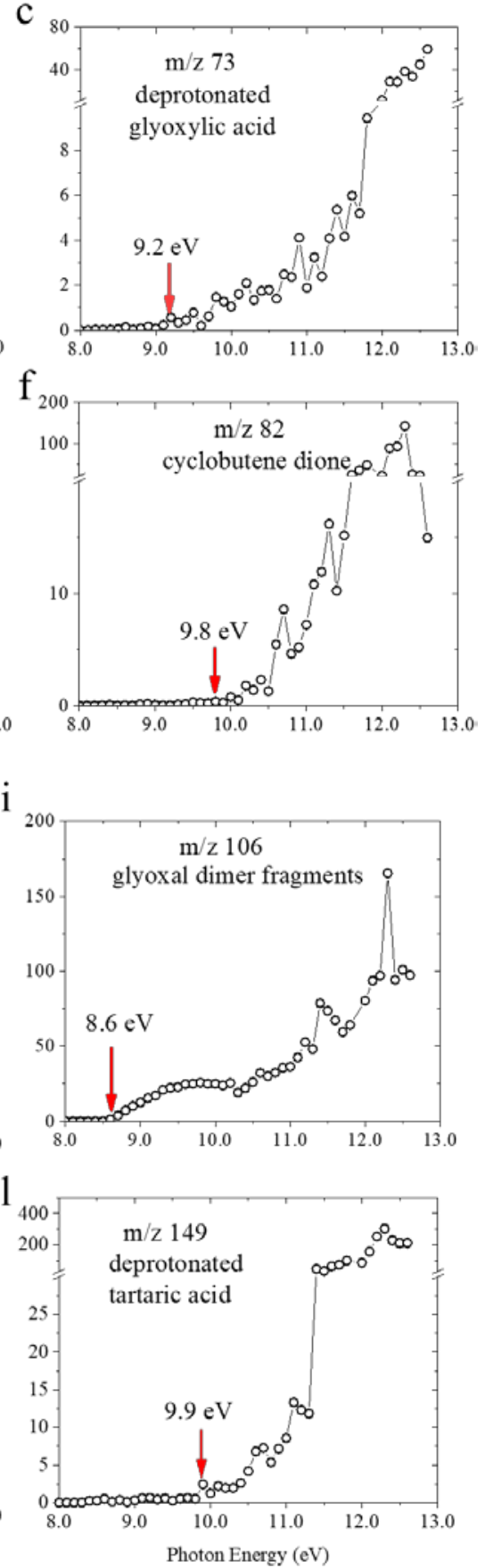
$\mathrm{m}$
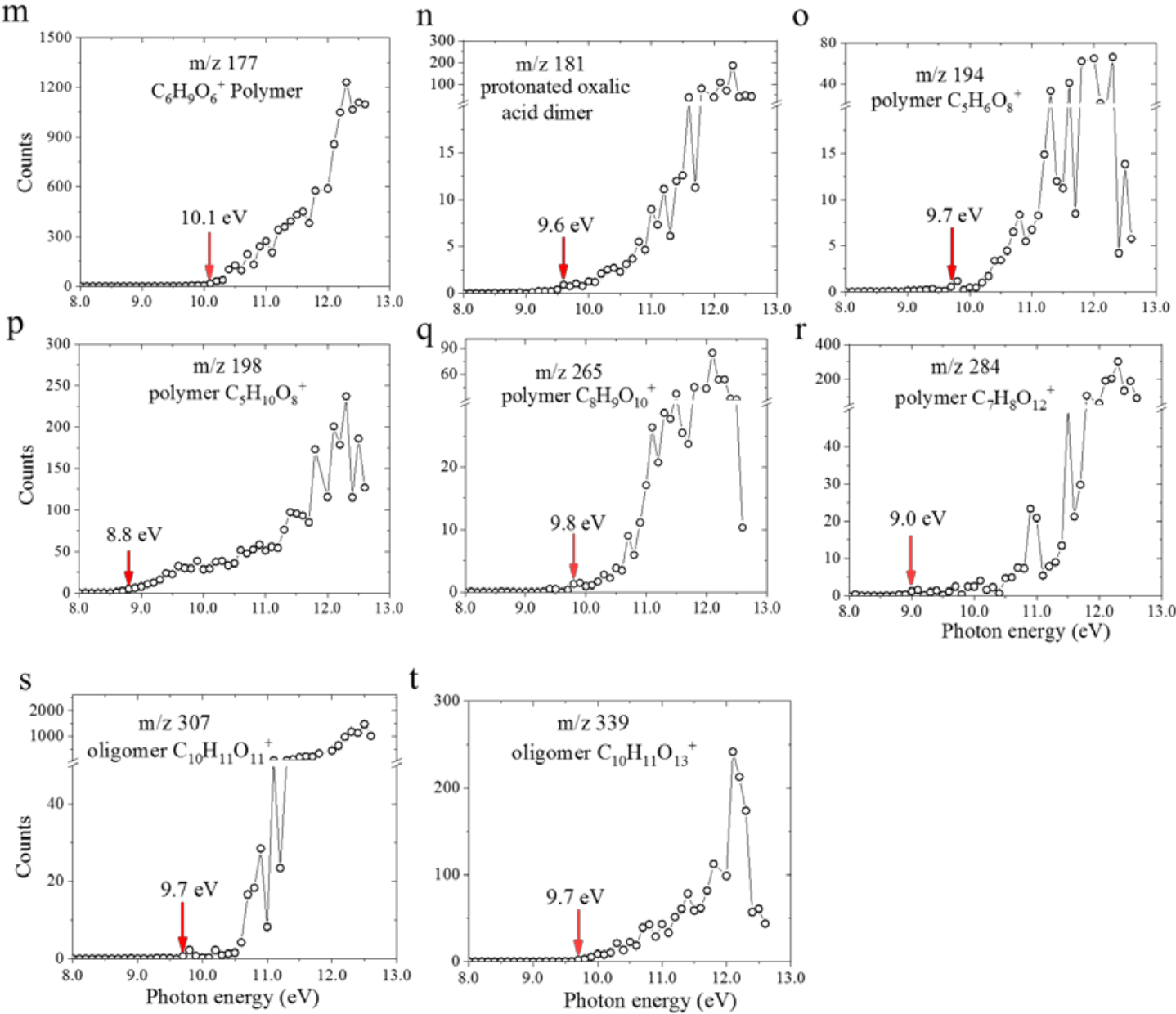

Fig. S5. Determination of AEs of key products from the $4 \mathrm{hr}$. UV aging data. Red arrows point to the onset of PIE curves.

AEs of selected photochemical reaction products determined from $4 \mathrm{hr}$. UV aging observations were depicted in Fig. S5. The AEs of key products agreed with those from the $2 \mathrm{hr}$. UV aging sample shown in Fig. 3 and Fig. S4. This result confirmed that AEs did not change with UV aging time as expected. 


\section{Supporting Tables}

Table S1. Summary of experimental conditions.

\begin{tabular}{|c|c|c|c|c|}
\hline $\begin{array}{l}\text { experimental } \\
\text { name }\end{array}$ & composition and treatment & PIE range & $\begin{array}{l}\text { PIE } \\
\text { step }\end{array}$ & $\mathrm{m} / \mathrm{z}$ range \\
\hline $\begin{array}{l}4 \mathrm{hr} . \mathrm{UV} \\
\text { reaction }\end{array}$ & $\begin{array}{c}5 \mathrm{mM} * \text { gly }+20 \mathrm{mM} \mathrm{H}_{2} \mathrm{O}_{2}(4 \mathrm{hr} . \mathrm{UV} \\
\text { exposure })\end{array}$ & $\begin{array}{c}8.0-12.6 \\
\mathrm{eV}\end{array}$ & $0.1 \mathrm{eV}$ & $0-600$ \\
\hline $\begin{array}{l}2 \mathrm{hr} . \mathrm{UV} \\
\text { reaction }\end{array}$ & $\begin{array}{c}5 \mathrm{mM} \text { gly }+20 \mathrm{mM} \mathrm{H}_{2} \mathrm{O}_{2}(2 \mathrm{hr} . \mathrm{UV} \\
\text { exposure })\end{array}$ & $\begin{array}{c}8.0-12.6 \\
\mathrm{eV}\end{array}$ & $0.1 \mathrm{eV}$ & $0-600$ \\
\hline $\begin{array}{l}1 \mathrm{hr} . \mathrm{UV} \\
\text { reaction }\end{array}$ & $\begin{array}{c}5 \mathrm{mM} \text { gly }+20 \mathrm{mM} \mathrm{H}_{2} \mathrm{O}_{2}(1 \mathrm{hr} . \mathrm{UV} \\
\text { exposure })\end{array}$ & $\begin{array}{c}8.0-11.0 \\
\mathrm{eV}\end{array}$ & $0.1 \mathrm{eV}$ & $0-400$ \\
\hline glyoxal control & 5 mM gly (no UV exposure) & $\begin{array}{c}8.0-12.6 \\
\mathrm{eV}\end{array}$ & $0.1 \mathrm{eV}$ & $0-600$ \\
\hline
\end{tabular}

*gly: glyoxal solution, prepared by glyoxal (40\% wt. solution in water, electrophoresis grade) dissolved in deionized (DI) water (18.2 M 2 )

Four samples, including 1 hr., 2 hr., 4 hr. UV aging, and glyoxal control, were prepared and their descriptions were summarized in Table S1. SPI-MS measurements were acquired using photon energies from 8.0 to $12.6 \mathrm{eV}$ for the glyoxal control, $4 \mathrm{hr}$. and $2 \mathrm{hr}$. samples and 8.0 to $11.0 \mathrm{eV}$ for the $1 \mathrm{hr}$. sample, respectively, with $0.1 \mathrm{eV}$ step to obtain the PIE curves of key products. These experiments were performed in two separate beam trips due to limited beamtime in each trip. In total, 172 experimental datasets were obtained in this study. The observed key products that were less than $\mathrm{m} / \mathrm{z} 400$ are consistent between the two trips, thus the chemical reaction was consistent although the $\mathrm{m} / \mathrm{z}$ range was different due to the instrument setup. 
Table S2. List of significant PDMS related peaks observed in the positive ion mode.

\begin{tabular}{cccc}
\hline observed m/z & suggested formula & reference & *relative counts \\
\hline 133 & $\mathrm{C}_{3} \mathrm{H}_{9} \mathrm{O}_{2} \mathrm{Si}_{2}$ & 9 & $0.012 \%$ \\
147 & $\mathrm{C}_{5} \mathrm{H}_{15} \mathrm{OSi}_{2}$ & 9 & $0.052 \%$ \\
221 & $\mathrm{C}_{7} \mathrm{H}_{21} \mathrm{O}_{2} \mathrm{Si}_{3}$ & 9 & $0.117 \%$ \\
239 & $\mathrm{C}_{4} \mathrm{H}_{15} \mathrm{O}_{4} \mathrm{Si}_{4}$ & 9 & $0.001 \%$ \\
281 & $\mathrm{C}_{9} \mathrm{H}_{27} \mathrm{O}_{5} \mathrm{Si}_{5}$ & 9 & $0.111 \%$ \\
295 & $\mathrm{C}_{9} \mathrm{H}_{27} \mathrm{O}_{3} \mathrm{Si}_{4}$ & 9 & $0.169 \%$ \\
297 & $\mathrm{C}_{8} \mathrm{H}_{25} \mathrm{O}_{4} \mathrm{Si}_{4}$ & 9 & $0.042 \%$ \\
355 & $\mathrm{C}_{9} \mathrm{H}_{27} \mathrm{O}_{5} \mathrm{Si}_{5}$ & 9 & $0.186 \%$ \\
369 & $\mathrm{C}_{11} \mathrm{H}_{33} \mathrm{O}_{4} \mathrm{Si}_{5}$ & 9 & $1.471 \%$ \\
429 & $\mathrm{C}_{11} \mathrm{H}_{33} \mathrm{O}_{6} \mathrm{Si}_{6}$ & 9 & $0.196 \%$ \\
443 & $\mathrm{C}_{13} \mathrm{H}_{39} \mathrm{O}_{5} \mathrm{Si}_{6}$ & 9 & $0.061 \%$ \\
503 & $\mathrm{C}_{13} \mathrm{H}_{39} \mathrm{O}_{7} \mathrm{Si}_{7}$ & 9 & $0.097 \%$ \\
577 & $\mathrm{C}_{15} \mathrm{H}_{45} \mathrm{O}_{8} \mathrm{Si}_{8}$ & 9 & $0.004 \%$ \\
591 & $\mathrm{C}_{17} \mathrm{H}_{51} \mathrm{O}_{7} \mathrm{Si}_{8}$ & 9 & $0.061 \%$ \\
\hline $0+5$ & -- & & $2.581 \%$ \\
\hline
\end{tabular}

* relative counts: peak counts proportion of overall counts from $2 \mathrm{hr}$. UV at $12.0 \mathrm{eV}$.

Interferences that may come from PDMS were summarized in Table S2. The relative counts of all integrated interference peaks only account for $2.58 \%$ of total ion counts, which implied that PDMS had negligible effect on the peak identification in the SPI-MS spectra. 
Table S3. Proposed new pathways of glyoxal photochemical reactions at the a-l interface detected by in situ liquid VUV-SPIMS.

\begin{tabular}{|c|c|}
\hline species & reaction pathways \\
\hline formic acid & $\mathrm{CH}(\mathrm{OH})_{2} \mathrm{CH}_{2}(\mathrm{OH})+\mathrm{HCOOH}+h v \rightarrow \mathrm{C}_{3} \mathrm{H}_{6} \mathrm{O}_{5}$ \\
\hline \multirow{2}{*}{ oxalic acid } & $\mathrm{HOOCCOOH} \rightarrow(\mathrm{HOOCCOOH})_{2}$ \\
\hline & $(\mathrm{HOOCCOOH})_{2}+\mathrm{CHOCH}_{2} \mathrm{HOCOOH}+h v \rightarrow \mathrm{C}_{7} \mathrm{H}_{8} \mathrm{O}_{12}$ \\
\hline \multirow{2}{*}{ succinic acid } & $\mathrm{HOOCCH}_{2} \mathrm{CH}_{2} \mathrm{COOH}+\mathrm{CHOCH}_{2} \mathrm{OH}+h v \rightarrow \mathrm{C}_{6} \mathrm{H}_{9} \mathrm{O}_{6}$ \\
\hline & $\mathrm{HOOCCH}_{2} \mathrm{CH}_{2} \mathrm{COOH}+\mathrm{HOOCCHOHCHOHCOO}+\mathrm{CH}_{2} \mathrm{OHCOOH}+h v \rightarrow \mathrm{C}_{10} \mathrm{H}_{11} \mathrm{O}_{11}$ \\
\hline \multirow{3}{*}{ tartaric acid } & $\mathrm{HOOCCHOHCHOHCOOH}+\mathrm{CH}_{2} \mathrm{OHCHOHCOOH}+h v \rightarrow \mathrm{C}_{8} \mathrm{H}_{9} \mathrm{O}_{10}$ \\
\hline & $\mathrm{HOOCCHOHCHOHCOOH}+\mathrm{CH}_{2} \mathrm{OHCOO}+\mathrm{CH}_{2} \mathrm{OHCHOHCOOH}+h v \rightarrow \mathrm{C}_{10} \mathrm{H}_{11} \mathrm{O}_{13}$ \\
\hline & $\mathrm{HOOCCHOHCHOHCOOH}+\mathrm{HCOOH}+h v \rightarrow \mathrm{C}_{5} \mathrm{H}_{6} \mathrm{O}_{8}$ \\
\hline
\end{tabular}




\section{Supporting Schemes}<smiles>O=C(O)C(O)C(O)O</smiles>

$\mathrm{m} / \mathrm{z} 122, \mathrm{C}_{3} \mathrm{H}_{6} \mathrm{O}_{5}^{+}$<smiles>O=C(O)CCC(=O)OC(O)CO</smiles>

$\mathrm{m} / \mathrm{z} 177, \mathrm{C}_{6} \mathrm{H}_{9} \mathrm{O}_{6}^{+}$<smiles>O=C(O)OC(=O)C(O)C(O)C(=O)O</smiles>

$\mathrm{m} / \mathrm{z} 194, \mathrm{C}_{5} \mathrm{H}_{6} \mathrm{O}_{8}^{+}$<smiles>O=C(O)CO[AlH]OC(=O)C(O)C(O)O</smiles>

$\mathrm{m} / \mathrm{z} 198, \mathrm{C}_{5} \mathrm{H}_{10} \mathrm{O}_{8}{ }^{+}$

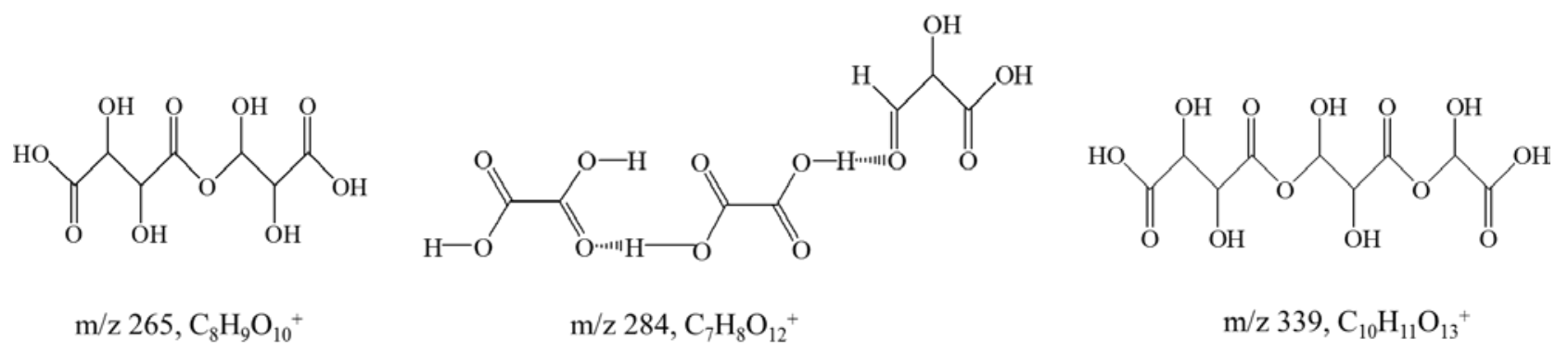

Scheme S1. Possible structures of representative new compounds identified by in situ liquid VUV-SPIMS

The proposed structures of representative new polymers and oligomers identified by in situ liquid VUV-SPIMS were depicted in Scheme S1. This scheme was a supplement to the expanded reaction flowchart described in Figure 4 in the main text and Table S3 in this Supporting Information. 


\section{References}

1. Yang, L.; Yu, X. Y.; Zhu, Z. H.; Thevuthasan, T.; Cowin, J. P., Making a hybrid microfluidic platform compatible for in situ imaging by vacuum-based techniques. J Vac Sci Technol A 2011, 29, (6).

2. Yang, L.; Yu, X. Y.; Zhu, Z. H.; Iedema, M. J.; Cowin, J. P., Probing liquid surfaces under vacuum using SEM and ToF-SIMS. Lab Chip 2011, 11, (15), 2481-2484.

3. Komorek, R.; Xu, B.; Yao, J.; Ablikim, U.; Troy, T. P.; Kostko, O.; Ahmed, M.; Yu, X. Y., Enabling liquid vapor analysis using synchrotron VUV single photon ionization mass spectrometry with a microfluidic interface. Rev.Sci. Instrum. 2018, 89, (11), 115105.

4. Komorek, R.; Xu, B.; Yao, J.; Kostko, O.; Ahmed, M.; Yu, X. Y., Probing sulphur clusters in a microfluidic electrochemical cell with synchrotron-based photoionization mass spectrometry. Phys. Chem. Chem. Phys. 2020, 22, (26), 14449-14453.

5. Zhang, F.; Yu, X.; Sui, X.; Chen, J.; Zhu, Z.; Yu, X. Y., Evolution of aqSOA from the AirLiquid Interfacial Photochemistry of Glyoxal and Hydroxyl Radicals. Environ. Sci. Technol. 2019, 53, (17), 10236-10245.

6. Sui, X.; Zhou, Y. F.; Zhang, F.; Chen, J. M.; Zhu, Z. H.; Yu, X. Y., Deciphering the aqueous chemistry of glyoxal oxidation with hydrogen peroxide using molecular imaging. Phys. Chem. Chem. Phys. 2017, 19, (31), 20357-20366.

7. Bell, F.; Ruan, Q. N.; Golan, A.; Horn, P. R.; Ahmed, M.; Leone, S. R.; Head-Gordon, M., Dissociative photoionization of glycerol and its dimer occurs predominantly via a ternary hydrogen-bridged ion-molecule complex. J. Am. Chem. Soc. 2013, 135, (38), 14229-39.

8. McGlynn, S. P.; Meeks, J. L., Photoelectron spectra of carbonyls, carbonates, oxalates, and esterification effects. J. Electron Spectrosc. Relat. Phenom. 1976, 8, 85-93.

9. Fouquet, T. Mass Spectrometry of Synthetic Polysiloxanes From linear models to plasmapolymer networks. Aix-Marseille University, France, Public Research Centre Henri Tudor, Luxembourg Aix-Marseille University, France, 2012. 